ORIGINAL ARTICLE

\title{
STATUS OF INDIGENOUS TREE SPECIES REGENERATION UNDER EXOTIC PLANTATIONS IN BELETE FOREST, SOUTH WEST ETHIOPIA
}

\author{
Kitessa Hundera
}

\begin{abstract}
The potential for regeneration of native woody species in exotic plantation stands and in the adjacent natural forest in Belete forest was studied. The objective of the study was to assess the diversity and density of the naturally regenerated woody species in plantations at Belete forest. Vegetation assessment within the stands was conducted using a line transect survey using square plot of size $10 \mathrm{~m} X 10 \mathrm{~m}$ which were established at $100 \mathrm{~m}$ intervals along line transects which were $100 \mathrm{~m}$ apart. A total of 60 woody plant species belonging to 50 genera and 31 families were recorded regenerating under the canopy of exotic plantations and a natural forest at Belete forest. Only 40 of the species were found in the plantations while 20 of them found only in the natural forest. The highest density of regeneration was recorded for Pinus patula followed by Cuppressus lucitanica. Cuppressus lucitanica plantation stand exhibited the highest value of Shannon diversity and evenness (2.5 and 0.84) followed by Eucalyptus saligna (2.13 and 0.83). Highest similarity index was observed between the plantation stands of Cuppressus lucitanica and Eucalyptus saligna (0.67). On the other hand the Cuppressus lucitanica and Eucalyptus camaldulensis plantation stands showed relatively weak similarity (0.36). Pinus patula and Cuppressus lucitanica plantations had the highest similarity to the natural forest. The regeneration of native woody species under the canopies of exotic plantations in moist montane forest areas suggests the possibility of restoring degraded areas in southwestern Ethiopia using these exotic plantation stands.
\end{abstract}

Key words: Exotic, Regeneration, Belete forest, Restoration

* Department of Biology, Jimma University, E-mail: Kitessa.hundera@ju.edu.et 


\section{INTRODUCTION}

Natural forests in Ethiopia are declining rapidly due to their conversion to arable lands coupled with unwise and excessive utilization triggered by increasing population growth. This had and continues to have serious consequences on various ecosystems in Ethiopia.

With the objective of satisfying the increasing demand for wood, relieving the pressure from natural forests and rehabilitating lands in Ethiopia, forest tree plantations have been initiated since the turn of this century, mainly with introduced species of Eucalyptus, Cupressus, Acacia, Pinus, Cassuarina, etc (Amare Getahun, et al. 1990).

Plantation establishments using exotic species have both advantages and disadvantages (Lugo, 1992). The potential advantages includes: a) readily available information on propagation techniques, silvicultural behavior and management practices of the species; b) relatively fast growing rates, and provision of wood that can be used for various purposes in a relatively short period of time. In addition, exotic plantations facilitate the regeneration of native species under their canopy and catalyze the subsequent succession processes (Lugo, 19992; Parrotta et al, 1997). It improves degraded lands by stabilizing soils, improving soil nutrient status and increasing soil organic matter through enhancing of aboveground litter production (Lugo, 1992).

The potential disadvantages include: a) unforeseen risks, such as problems of adaptability and susceptibility of the species to diseases, b) negative impacts on the environment, e.g. undesirable changes in the physical, chemical and biological conditions of the soil; and c) undesirable invasion /colonization of arable lands, pastures and native vegetation as well as displacement of the local flora (Feyera Senbeta et al. 2002).

Despite the various benefits that accrue as a result of establishing plantations of exotic species, there is a growing concern among people regarding the disadvantage of such ventures resulting in reluctance or resistance of people to the introduction and establishment of exotic species. However, little research work has been undertaken to elucidate the harmful and beneficial impacts of exotic plantations. In the absence of empirical evidences, any claim against the establishment of exotic species can not be warranted, in countries such as Ethiopia where there is a desperate and urgent need of expanding the forest resource base to meet the ever-increasing demand for wood (Bone et al.1997; Feyera Senbeta and Demel Teketay, 2001).

Recently many studies have indicated that forest plantations can foster the regeneration of native woody species under their canopy and catalyze the subsequent succession processes (Bone et al. 1997; Yitebitu Moges, 1998; Feyera Senbeta and Demel Teketay, 2001; Feyera Senbeta et al. 2002; Getachew Tesfaye and Abiyot Berhanu, 2006).

While the catalytic role of plantations in enhancing native woody regenerations as well as improving degraded lands have been widely observed in many countries, understanding of the mechanisms and processes involved is quite limited. For instance, knowledge on the relationships among the catalyzing effect of tree plantations on succession of forests, the role of dispersal mode, origin of seeds (seed bank or seed rain), and the effect of management and types of species, is scanty (Yitebitu Moges, 1998; Feyera Senbeta and Demel Teketay, 2001). 
Monitoring composition, densities and the role of seed rain, soil seed banks and advance regeneration in the colonization of indigenous woody species following plantation establishment is of paramount importance. In addition, changes in the biotic and physical components of the plantation site, both temporally and spatially are gaps that need investigation in the future. Understanding of the processes that may allow us to develop plantation management for provision of urgently required goods and services, coupled with enhancement and maintenance of biodiversity, are very essential. Therefore, the objective of this study was to assess the diversity, density, and height class distribution of the naturally regenerated woody species in plantations at Belete forest.

\section{MATERIALS AND METHODS}

Description of the study area

Belete forest is situated in Shabe Sombo wereda, Jimma zone, Oromiya National regional state; $375 \mathrm{~km}$ south west of Addis Ababa and it is part of the Belete Gera National Forest Priority Area and located at longitudes between $36^{\circ} 15^{\prime} \mathrm{E}$ and $36^{\circ} 45^{\prime} \mathrm{E}$ and latitudes $7^{0} 30^{\prime} \mathrm{N}$ and $7^{0} 45^{\prime} \mathrm{N}$ (Belete Gera PFMP, 2006).
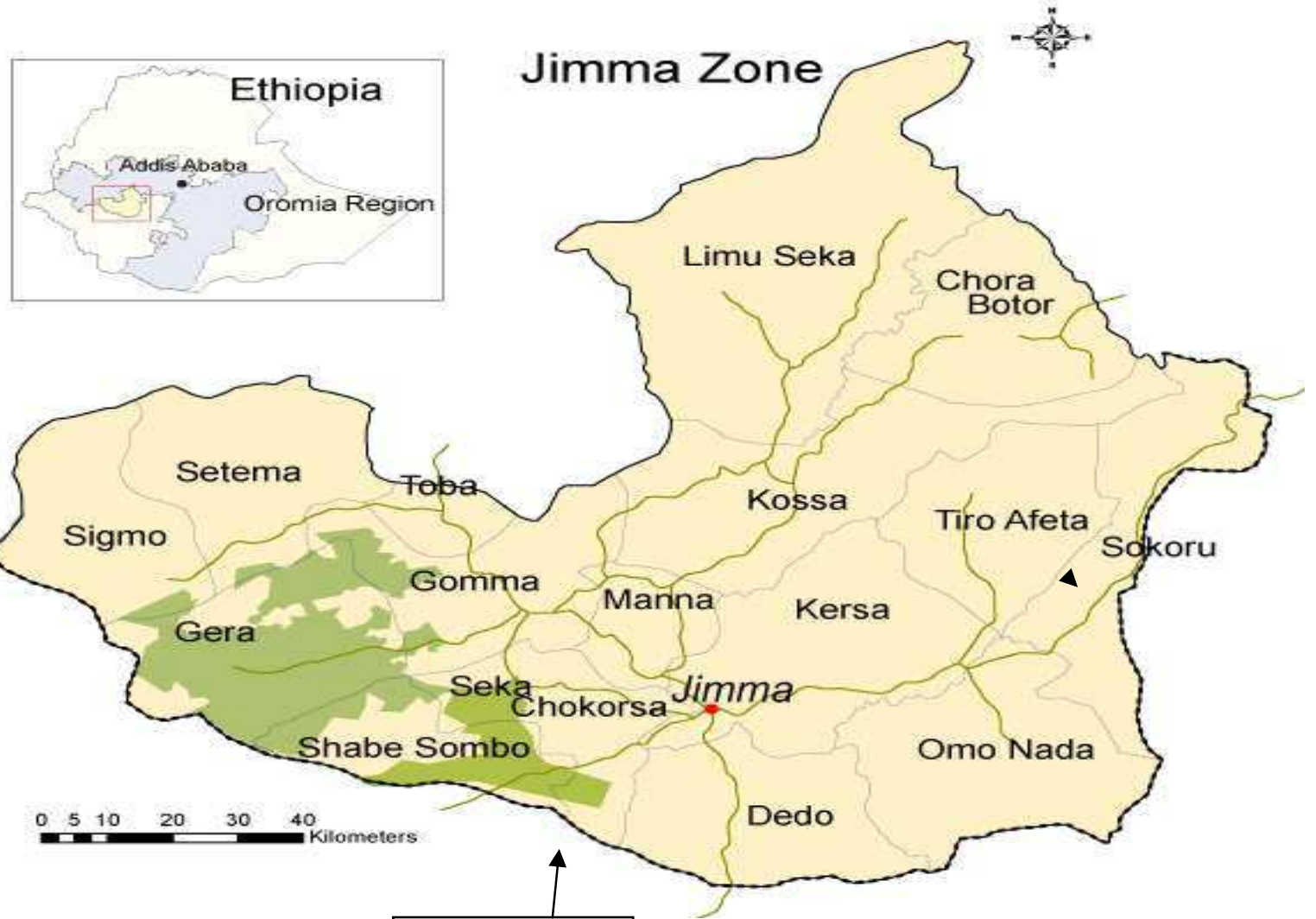

Figure 1. Map of the study area

\section{Belete forest}


Soils of the study area are largely volcanic in origin and relatively fertile and the dominant soil types are nitosols ((Bridges et al. 1998). Tertiary volcanic and related volcano-clastic sediments underlie the area (Murphy, 1968). The mean annual rainfall of the area is between $1800 \mathrm{~mm}$ and 2300 $\mathrm{mm}$ with maximum rainfall between the months of June and September. The mean annual temperature of the area is between $15^{\circ} \mathrm{C}$ and $22^{\circ} \mathrm{C}$ (EMA, 1988).

In Belete forest there is huge plantation of exotic tree species such as Eucalyptus, Cupressus, Pinus and Cassuarina spp. with different age and size.

\section{Methods Of Data Collection}

Vegetation assessment within the stands was conducted using a line transect survey. 32 plots of size $10 \mathrm{~m} \mathrm{X} 10 \mathrm{~m}$ were established at $100 \mathrm{~m}$ intervals along line transects which were $100 \mathrm{~m}$ apart. The starting point of all line transects were located randomly in each stand. The plots were laid down in each stand and the first plot was located randomly. All sample plots were located at least $50 \mathrm{~m}$ from plantation edges/road to avoid edge effect.
In each plot, all of the naturally regenerated woody species were identified and counted. When identification proved difficult in the field, specimens were collected for identification. Species identification was conducted at Jimma University Herbarium. The nomenclature of plant species follows Hedberg and Edwards (1989, 1995) and Edwards, et al. (1995, 1997, 2000).

\section{Method Of Data Analysis}

The Shanon-Wiener diversity index ( $\left.\mathrm{H}^{\prime}\right)$ and Shanon evenness (E) were computed following Magurran (1988). Similarity in species composition among the plantation stands was computed using Sorensen Similarity index (Kent and Coker, 1993).

\section{RESULTS}

There is a variation in diameter at breast height (DBH) and height among the plantation stands (Table 1). Mean basal area, mean DBH and crown cover is lower for E. camaldulensis. The density of planted trees showed considerable variation among the plantation stands. The density (stem/ha) of Cuppresus lucitanica is greater than the four species while that of Pinus patula is the lowest (Table 1).

Table 1. Characteristics of plantation stands sampled in Belete forest, 2008

\begin{tabular}{|c|c|c|c|c|c|}
\hline species & $\begin{array}{l}\text { Mean basal } \\
\text { area } \mathrm{cm}^{2}\end{array}$ & $\begin{array}{l}\text { Mean DBH } \\
\mathrm{cm}\end{array}$ & $\begin{array}{l}\text { Mean } \\
\text { height } m\end{array}$ & Stem/ha & $\begin{array}{l}\text { Crown } \\
\text { cover } \\
(\%)\end{array}$ \\
\hline $\begin{array}{l}\text { Cuppresus } \\
\text { lucitanica }\end{array}$ & 16 & 34 & 25 & 1000 & 80 \\
\hline $\begin{array}{l}\text { Eucalyptus } \\
\text { saligna }\end{array}$ & 21 & 26 & 28 & 675 & 65 \\
\hline E. camaldulensis & 13 & 21 & 24 & 456 & 40 \\
\hline Pinus patula & 35 & 30 & 28 & 190 & 85 \\
\hline
\end{tabular}


A total of 60 woody plant species belonging to 50 genera and 31 families were recorded regenerating under the canopy of exotic plantations and a natural forest at Belete forest (Table 2). Only 40 of the species were found in the plantations while 20 of them found only in the natural forest. Six of the regenerated species in the exotic plantations belongs to the upper and medium canopy tree species in the adjacent natural forest (Table 2). Fifteen of the regenerating species were found in four of the exotic plantations while the remaining were found in one or more of the four exotic plantations (Table 2). Rhytrigea neglecta, Pterolobium stellatum, Oxyanthus spaceous, Galineria saxifraga, and Calpurina aurera are the most common regenerating woody species (Table 2).

Table 2. Density of regenerating species/ ha under the exotic plantations in Belete forest, 2008

\begin{tabular}{|c|c|c|c|c|c|c|}
\hline Species & Family & NF & EC & CL & PP & ES \\
\hline Acacia abyssinica & Fabaceae & 15 & - & - & - & - \\
\hline Acacia sp. & Fabaceae & 24 & - & - & - & - \\
\hline Acanthus pubescence & Acanthaceae & 95 & 50 & 100 & 100 & - \\
\hline Albiza gumifera & Fabaceae & 40 & 10 & 15 & 40 & 25 \\
\hline Albiza schimperiana & Fabaceae & 50 & 12 & 23 & 35 & 43 \\
\hline Allophylus abyssinica & Sapindaceae & 550 & & 650 & 100 & 100 \\
\hline Macaranga capensis & euphorbiaceae & 35 & 12 & 23 & - & 12 \\
\hline $\begin{array}{l}\text { Aningeria- } \quad \text { adolfi- } \\
\text { friedrichi }\end{array}$ & Sapotaceae & 25 & - & - & - & - \\
\hline Apodytes dimidiata & Icacianaceae & 28 & - & - & - & - \\
\hline Bersama abyssinica & Melianthaceae & 350 & 230 & 150 & 100 & 120 \\
\hline Brucea antidysentrica & Simarobiaceae & 30 & - & 50 & 400 & 35 \\
\hline Calpurina aurera & Fabaceae & 580 & 350 & 250 & 480 & 300 \\
\hline Carrisa spinarium & Apocynaceae & 25 & 15 & 50 & 200 & 150 \\
\hline Celtis Africana & Ulmaceae & 25 & 30 & 35 & 60 & - \\
\hline Clausenia anisata & Rutaceae & 350 & 45 & 120 & 60 & - \\
\hline Coffea arabica & Rubiaceae & 45 & - & - & - & - \\
\hline Combretum paniculatum & Combertaceae & 36 & 35 & 35 & & 25 \\
\hline Cordia africana & Boraginaceae & 35 & 40 & 35 & 60 & - \\
\hline Croton macrostachyus & Euphorbiaceae & 450 & 300 & 200 & 400 & 45 \\
\hline Diosporyus abyssinica & Ebenaceae & 25 & - & - & - & - \\
\hline Discopodium peninervum & Solanaceae & 340 & - & 200 & 200 & - \\
\hline Dombeya torrida & Striculariaceae & 15 & 10 & - & 40 & 35 \\
\hline Ehertia cymosa & Boraginaceae & 45 & - & - & 125 & 245 \\
\hline Ekebergia capensis & Meliaceae & 25 & - & - & - & - \\
\hline Embelia schimperi & Myrsinaceae & 250 & - & 200 & 400 & - \\
\hline Euclea racimosa & Ebenaceae & 90 & 35 & - & 40 & - \\
\hline Ficus sychomorus & Moraceae & 15 & - & - & - & - \\
\hline Ficus thoningii. & Moraceae & 25 & - & - & - & - \\
\hline Ficus vasta & Moraceae & 15 & - & - & - & - \\
\hline Galineria saxifraga & Rubiaceae & 250 & 600 & 1150 & 120 & 120 \\
\hline
\end{tabular}


Table 2. continued

$\begin{array}{lllllll}\text { Species } & \text { Family } & \text { NF } & \text { EC } & \text { CL } & \text { PP } & \text { ES } \\ \text { Ilex mitis } & \text { Aquifoliaceae } & 25 & - & - & - & - \\ \text { Jasmium abyssinica } & \text { Oleaceae } & 200 & - & 50 & 100 & - \\ \text { Maesa lanceolata } & \text { Myrsinaceae } & 240 & 100 & 750 & 40 & 75 \\ \text { Maytenus gracilipes } & \text { Celasteraceae } & 24 & 120 & 235 & 234 & 75 \\ \text { Maytenus arbutifolia } & \text { Celasteraceae } & 35 & 200 & - & 43 & - \\ \text { Maytenus undata } & \text { Celasteraceae } & 250 & 234 & - & - & 235 \\ \text { Miletia ferugnea } & \text { Fabaceae } & 35 & 40 & 50 & 40 & - \\ \text { Paveta abyssinica } & \text { Rubiacea } & 25 & 50 & 50 & 100 & - \\ \text { Ocimum lamifolium } & \text { Lamiaceae } & 70 & 35 & 69 & 47 & 25 \\ \text { Olea capensis } & \text { Oleaceae } & 25 & - & - & - & - \\ \text { Olea welwetschi } & \text { Oleaceae } & 350 & - & - & - & - \\ \text { Oxyanthus speciosus } & \text { Rubiaceae } & 300 & 200 & 450 & 100 & 50 \\ \text { Pittosporum viridiflorum } & \text { Pittosporaceae } & 25 & - & - & - & - \\ \text { Podocarpus falcatus } & \text { Podocarpaceae } & 15 & - & - & - & - \\ \text { Polyscias fulva } & \text { Araliaceae } & 35 & - & - & - & - \\ \text { Prunus africana } & \text { Rosaceae } & 25 & - & 10 & 30 & - \\ \text { Pterolobium Stellatum } & \text { Fabaceae } & 200 & 200 & 230 & 145 & 250 \\ \text { Rhamnus prinoides } & \text { Rhamnaceae } & 150 & 15 & 45 & 100 & - \\ \text { Rhytrigea neglecta } & \text { Rubiaceae } & 2700 & 2000 & 1200 & 2600 & 1200 \\ \text { Rothmannia urcelliformis } & \text { Rubiaceae } & 29 & - & - & - & - \\ \text { Rubus apetalus } & \text { Rubiaceae } & 35 & - & 200 & 400 & - \\ \text { Rubus steudneri } & \text { Rubiaceae } & 34 & - & 100 & 600 & - \\ \text { Sapium ellipticum } & \text { Euphorbiaceae } & 35 & - & - & - & - \\ \text { Schefleria abyssinica } & \text { Araliaceae } & 45 & - & - & - & - \\ \text { Senna didymobottra } & \text { Fabaceae } & 38 & - & 150 & 680 & - \\ \text { Syziguim guinensee } & \text { Myrtaceae } & 500 & 30 & 100 & 60 & 50 \\ \text { Teclea noblis } & \text { Rutaceae } & 20 & 45 & 35 & 100 & \\ \text { Vernonia amygdalina } & \text { Asteraceae } & 30 & - & - & - & - \\ \text { Vernonia auriculifera } & \text { Asteraceae } & 250 & 1000 & - & 85 & - \\ \text { Vepris dainellii } & \text { Rutaceae } & 230 & 34 & 150 & 60 & 35 \\ \text { Total sp. } & & 60 & 36 & 40 & 40 & 24 \\ \text { Total density } & & 10058 & 6113 & 7200 & 8564 & 3274 \\ & & & & & & \end{array}$

NF, Natural forest; EC, Eucalyptus camaldulensis; ES, E. Saligna; PP, Pinus patula; CL, Cuppressus lucitanica 
The different plantation stands showed marked variation in the number of regenerating woody plant species under their canopies. The highest number of species was recorded under Cupressus lucitanica and Pinus patula each with 40 species and the least under Eucalyptus saligna with only 24 species (Table 2 ).
Variation in density of regenerated species

There is a considerable variation in the density of regenerated plants in the plantation stands. The highest density of regeneration (number of regenerated individuals per hectare) was recorded for Pinus patula followed with Cuppressus lucitanica (Table 2).

\section{Diversity and similarity of regeneration under plantation stands}

Table 3. Shanon Diversity and Evenness of the Plantation stands in Belete forest, 2008

Plantation stand

Cuppresus lucitanica

Eucalyptus camaldulensis

E. saligna

Pinus patula
$\mathrm{H}^{\prime}$

2.5

2.02

2.13

1.99
Evenness (E)

0.84

0.69

0.83

0.78
Shannon diversity index and evenness showed considerable variation among the plantation stands. Cuppressus lucitanica plantation stand exhibited the highest value of Shannon diversity and evenness (2.5 and 0.84 ) followed by Eucalyptus saligna (2.13 and 0.83) (Table 3).
Highest similarity index was observed between the plantation stands of Cuppressus lucitanica and Eucalyptus saligna (0.67) (Table 4). On the other hand, the Cuppressus lucitanica and Eucalyptus camaldulensis plantation stands showed relatively weak similarity (0.36). Pinus patula and Cuppressus lucitanica plantations had the highest similarity to the natural forest (Table 4).

Table 4. Sorrenson similarity index among plantation stands in Belete forest, 2008

$\begin{array}{lllll} & \text { PP } & \text { EC } & \text { CL } & \text { ES } \\ \text { EC } & 0.63 & - & & \\ \text { CL } & 0.64 & 0.36 & - & - \\ \text { ES } & 0.56 & 0.45 & 0.67 & 0.57 \\ \text { NF } & 0.8 & 0.67 & 0.8 & \text {. }\end{array}$

NF, Natural forest; EC, Eucalyptus camaldulensis; ES, E. Saligna; PP, Pinus patula; CL, Cuppressus lucitanica 


\section{DISCUSSION}

The total number of regenerated species at the present study site (60 species) is very close to previous reports from Munessa Shashemene (55) (Feyera Senbeta, et al. 2002) but higher than in the Menagesha forest (37) (Feyera Senbeta and Demel Teketay, 2001). Of the plant species regenerated under the plantation stand, Syzigium guinensee, Albizia gumifera and A. schimperiana are found to be canopy species that also occur in natural forest. The most common timber species such as Aningeria adolfi-friedrchii, Afrocarpus falcatus and Prunus africana were absent under the canopies of exotic plantation stands.

In the present study, species richness was higher in the Pinus patula and Cuppressus lucitanica plantations each with 40 species but E. globulus had higher number of species in Menagesha forest (Feyera Senbeta, et al. 2002) with 27 species and Eucalyptus camaldulensis with 24 species (Getachew Tesfaye and Abiot Berhanu, 2006). The density of regenerated plants ranged from 3274 to 8564 individuals /ha.

These results are within the range that have been reported from Munessa Shashemene forest (Feyera Senbeta, et al. 2002) and relatively lower than the Jiren forest reported by Getachew Tesfaye and Abiot Berhanu (2006). The variation in density of the regenerated species could be attributed to site specific differences, difference due to species composition or management history of the forest.

The shanon-diversity index was higher for Cuppressus lucitanica in the present study while it was highest for E. camaldulensis in Jiren Forest (Getachew Tesfaye and Abiot Berhanu, 2006) and for E. globulus for Menagesha forest (Feyera Senbeta and Demel Teketay, 2001). Getachew Tesfaye and Abiot Berhanu (2006) recommended that Eucalyptus plantation stand could be more preferred to other exotic species for the purpose of ecosystem restoration through exotic plantations and maintenance of biodiversity on degraded fields but this is not supported by the present study.

\section{Implications for restoration}

The regeneration of native woody species under the canopies of exotic plantations in moist montane forest areas suggests that it is possible to restore degraded areas in southwestern Ethiopia using these exotic plantation stands. The absence of regenerating important timber species such as Aningeria adolfi-friedrichi, Podocarpus falcatus and Prunus Africana can be attributed to scarcity of seed sources or the ecological requirements for seed germination and seedling growth of the species. In the restoration of degraded areas, knowledge of ecological factors such as availability of seed sources, environmental factors for seed germination and seedling growth of the species under the canopies of exotic plantations is very important.

\section{ACKNOWLEDGEMENTS}

I am indebted to the Research and Publication Office of the Faculty of Education for their financial support to conduct this study. I also would like to thank Nuredin Abduselam and Arega Tsegaye for their assistance during data collection. I appreciate comments of the anonymous reviewers for their critical comments. 


\section{REFERENCES}

Amare Getahun, Feyissa Abate. and Belay Gebre. 1991. A brief history of forestry research center (FRC) and forestry research in Ethiopia FRC, Addis Ababa.

Belete Gera Participatory Forest Project (PFMP) Annual report. 2006. JICA and Oromia Agriculture and Rural Developmen Bureau. Jimma, Ethiopia.

Bone,L., M. Laurence and Z. Magombo. 1997 the effect of Eucalptus camaldulensis (Dehn) plantation on native woodland recovery on Ulumba Mountains, Southern Malawi. Forest Ecology and management. 99: 83-99.

Bridges E.M., Batjes N.H. and achtergaele F.O. (eds) 1998. World reference base for soil resources - atlas. Acco, Leuven, Amersfoort.

EMA, 1988. National Atlas of Ethiopia. Ethiopian mapping Authority, Addis Ababa.

Edwards S., Mesfin Tadesse and Hedberg I. (Eds.) 1995. Flora of Ethiopia and Eritrea. Vol 2, Part 2.

Canellaceae to Euphorbiaceae. Addis Ababa University and Uppsala University, 456 pp.

Edwards S., Sebsebe Demissew and Hedberg I. (Eds). 1997. Flora of Ethiopia. Vol. 6.

Hydrocharitaceae to Arecaceae. The National Herbarium, Addis Ababa and Uppsala University, Uppsala, 586 pp.

Edwards S., Mesfin Tadesse., Sebsebe Demissew and Hedberg I. (Eds.)
2000. Flora of Ethiopia and Eritrea. Vol 2, Part 1.

Magnoliaceae to Flacourtiaceae. Addis Ababa University and Uppsala University, 532 pp.

Feyera Senbeta and Demel Teketay. 2001. Regenaration of indigenous woody species under the canopies of tree plantations in central Ethiopia. Tropical Ecology 42:175-185.Feyera Senbeta,

Demel Teketay and

Naslund, B. A. 2002. Native

woody species regeneration in exotic tree plantations at MunessaShashemene Forest, Southern Ethiopia. NewForests 24: 131145.

Getachew Tesfaye and Abiyot Berhanu, 2006. Regeneration of indigenous woody species in the understorey of exotic tree species plantations in southwestern Ethiopia.

Ethiop. J. Biol. Sci., 5:31-43

Hedberg I. and Edwards S. (Eds.) 1989. Flora of Ethiopia. Vol. 3.

Pittosporaceae to Araliaceae. The National Herbarium, Addis Ababa and Uppsala University, Uppsala, $659 \mathrm{pp}$.

Hedberg, I., and Edwards, S. (Eds.) 1995. Flora of Ethiopia and Eritrea, Vol. 7. Poaceae (Graminae). The National Herbarium, Addis Ababa University, Addis Ababa \& Department of Systematic Botany, Uppsala University, Uppsala.

Kent, M. and Coker, P. 1993. Vegetation Description and Analysis: A Practical Approach. John Wiley and sons. 384pp. 
Lugo, A. E. 1992. Comparison of tropical tree plantations with secondary forests of similar age. Ecological monograph 62:1-41.

Magurran, A. E. 1988. Ecological diversity and its measurement. Princeton University press, Princeton, 179 pp.

Murphy H. E. 1968. A Report on the Fertility Status and other Data on some Soils of Ethiopia. College of Agriculture, Haile Sellassie I University.
Parrotta, J.A., J.W. Turnbull and N. Jones.1997. catalyzing native forest regeneration on degraded tropical lands. Forest ecology and management 99:1-7.

Yitebitu Moges. 1998. The role of exotic plantation forests in fostering the regeneration of native trees in an Afromontane forest area in Ethiopia, M. Sc. thesis. Wage ningen Agricultural University, Wagenin 